\title{
The "Falun Gong Problem": Politics and the Struggle for the Rule of Law in China
}

\author{
Ronald C. Keith and Zhiqiu Lin*
}

\begin{abstract}
This article examines the CCP's "falun gong problem" with reference to PRC law and policy on "heretical cults," paying particular attention to the implications of this problem for the ongoing struggle to establish human rights under the rule of law. Official PRC commentary contends that the falun gong not only committed criminal acts but also wilfully sought to undermine the rule of law itself. Human rights critics and agencies, such as the US Commission on International Religious Freedom, have, on the other hand, attacked the PRC for a "repressive legal framework" that threatens human rights. The "falun gong problem" is an important chapter in the struggle for the rule of law in China, and it appears that the law has not been able to transcend the conceptual bias of past criminal law on counter-revolution. The related politicization of the law through a revived principle of "flexibility" challenges the internal process of criminal justice reform and the recent reform focus on the balance of human rights protection and public order.
\end{abstract}

This article examines the relation between the criminal justice treatment of the falun gong (FLG) and the Chinese struggle for the rule of law. It contends that the Chinese Communist Party's (CCP's) handling of its so-called "falun gong problem" has had a largely negative impact on criminal justice reform, as it was envisaged in the major revisions to the Criminal Procedural Law (CPL) and Criminal Law (CL) of 1996-97, and that it is important to analyse this impact in an ongoing assessment of criminal justice reform as a key component of China's continuing struggle to fashion a domestic rule of law.

The potential development of a rule of law in China has been controversial in light of competing assumptions concerning the nature and scope of contemporary regime change and the related political capacity for meaningful legal reform. Western scholars often subscribe to a mixed position, qualifying appreciation of positive legal change over the last 20 years with serious doubts about the genuine creation of a Chinese rule of law under the leadership of a Marxist-Leninist political party.

The struggle to maintain the rule-of-law principles such as the supremacy of law, all are equal before the law and judicial independence is ongoing in any jurisdiction, but it is especially problematic in the Chinese context of zheng-fa xitong which so deliberately combines the political and legal worlds. The zheng- $f a$ system often accepted the "spirit of the leader"; and it came with a jurisprudential doctrine of "flexibility" (linghuoxing) that casually presumed that policy, as interpreted by the Party leader, was more important than, and could even substitute for, the

*The authors would like to thank the Social Sciences and Humanities Research Council of Canada for related research funding.

(C) The China Quarterly, 2003 
National People's Congress' (NPC) comprehensive stipulation of law. ${ }^{1}$ And as Jerome Cohen once noted, this system naturally tends to a "type of patriarchal obliteration of the line between justice and administration."

In 1994, R.C. Keith noted that the law's "lofty dignity" could easily become "a casualty of social change" and that the struggle for the rule of law in China "has yet to resolve the integral paradox between a new political focus on the rule of law and a reflexive tendency to genuflect before the rule of man and the necessity of political unity." ${ }^{3}$ This 1994 analysis may have been overly optimistic in its assumption that a "retreat back into the heyday of policy as the soul of law is increasingly unlikely." ${ }^{4}$ In their latest book, the present authors suggested that " $\ldots$ the return to a rigid state instrumentalism based upon extreme class analysis would seem unimaginable," but that it is still possible that "the rule of law could be eviscerated within a soft corporatist strategy to perpetuate the CCP's power."

These analyses could not take take into full account the most recent impact of the criminal justice treatment of the $F L G$ on the struggle for the rule of law. Such treatment recalls the "heyday" of "policy is the soul of law" even though strictly speaking it is not grounded in the pre-1997 law on counter-revolution and related jurisprudence concerning the law's role in class struggle. The treatment of the " $F L G$ problem" is a distressing reminder of the paradox of legal reform and state power under CCP leadership. ${ }^{6}$

Pitman Potter has elaborated on the integrated political cultural and institutional correlations of Chinese law and politics. He concluded that the current reform approach to the rule of law is still "fundamentally instrumentalist." In 2001 Potter suggested contemporary legal reform "remains confined to the discourse of 'political-legal work' in which Party leadership continues as a dominant theme." ${ }^{\prime 7}$ However, he also acknowledged that the 1996-97 CPL/CL revision did lay some new groundwork for legal reform: “... driven by principles of fairness (gongzheng) and process (youxu) the [1996-97] revisions were to achieve a balance between punishing crime and safeguarding human rights by

1. On the distinction between "law" and "policy" as it relates to Party leadership, see the analysis of the views of Zhang Yongming and Li Buyun, in R.C. Keith, China's Struggle for the Rule of Law (London \& New York: Macmillan \& St. Martin's, 1994), p. 13.

2. Jerome Cohen, "The criminal process in the People's Republic of China: an introduction," Harvard Law Review, Vol. 79, No. 3 (January 1966), p. 470, as cited in Keith, China's Struggle for the Rule of Law, p. 40.

3. Ibid. p. 220.

4. Ibid. p. 218. "Policy is the soul of law" (zhengce shi falü de linghun), summed up the state's pre-eminent position vis-à-vis law. Policy was a priori to law, and in the absence of law it had the status of law.

5. Ronald C. Keith and Zhiqiu Lin, Law and Justice in China's New Marketplace (London: Palgrave, 2001), p. 245.

6. Pitman Potter discusses this in The Chinese Legal System: Globalization and Local Legal Culture (London \& New York: Routledge, 2001), p. 161.

7. Ibid. p. 11. 
requiring greater attention to evidence of guilt." Certainly, China's own jurists saw in this reform a new and powerful statement on how the law's "balance of values" synthesizes public order and human rights protection. ${ }^{9}$

In a recent study, which takes the measure of criminal justice before and after 1997, Ian Dobinson counterposes two views on the 1997 CL revision. In this account, some scholars, such as Keith and Lin, saw in the revision a trend towards a more rational and predictable system of criminal justice while others such as Jianfu Chen viewed the revision as mainly rhetorical. The latter asserts: "China's criminal justice system remains a crude and arbitrary tool of state control over enemies both real and imagined." While Dobinson suggests that it is too early to establish any trend line in China's struggle for the rule of law, he suggests that the $F L G$ crackdown supports "the continuation of state instrumentalism." 10

There is an ongoing policy dispute in the United States as to whether engagement with China has resulted in any "rule-of-law" dividend in the contemporary context of market reform. Stanley Lubman wrote in 1999 that Chinese legal reform had "failed to raise the position of the judicial system from its current level; it remains at the same level as other bureaucratic hierarchies of the state and lacks authority over them." While acknowledging that the $1996 \mathrm{CL}$ revision confirmed that "the terminology and concepts of the Maoist era have been left behind," he opined that the "subservient role of the courts" cannot be genuinely addressed as the result of "fundamental political decisions about the allocation of power within the Chinese state." In short, the criminal process is "still in the grip of CCP authoritarianism."

Ralph Peerenboom, in his 2002 study of China's rule of law, expressed some reservations as to how exclusively determining Party leadership and ideology are with respect to Chinese rule-of-law making. He suggested placing "less emphasis on socialist ideology and the intent of the leaders and more emphasis on context and the particular problems that China is confronting in establishing a law-based order." 12 Lubman placed "too much weight on ideology as an obstacle to the rule of law" and questions whether the transition to the rule of law "is possible only if the ideological limits of the ruling regime are overcome." ${ }^{13}$ Linda Chelan Li tended

8. Ibid. p. 107. 25-27.

9. For jurist debate on the "balance of values" see Keith and Lin, Law and Justice, pp.

10. Ian Dobinson, "The Criminal Law of the People's Republic of China (1997): real change or rhetoric," Pacific Rim Law and Policy Journal, Vol. 11, No. 1 (January 2002), p. 4

11. Stanley Lubman, Bird in a Cage: Legal Reform in China after Mao (Stanford: Stanford University Press, 1999), pp. 3, 168.

12. Here, Peerenboom cites Keith and Lin, Law and Justice in China's New Marketplace, p. 31. Randall Peerenboom, China's Long March Toward the Rule of Law (Cambridge: Cambridge University Press, 2002), p. 11, n. 32.

13. Peerenboom elaborates on Lubman's view as follows: "Given that for Lubman a transition to rule of law is possible only if the ideological limits of the ruling regime are overcome, it would seem that the ruling regime must either fall from power or abandon - or at minimum fundamentally revise - its socialist ideology, including the commitment to a leadership role for the Party." China's Long March, p. 24, n 30. 
to agree with Peerenboom. She recognized that China's political system is "under-insitutionalized," but she argued that it would be "oversimplistic ... to resign the law to an entirely instrumental position at the disposal of political leaders." 14

Heavy emphasis on state instrumentalism can play into the hands of the critics of engagement. In his recent remarks concerning the prospects for the rule of law after China's accession to the World Trade Organization, Lubman reiterated his "mixed" view of Chinese legal reform, noting that the symbolic reference to the rule of law in the 1999 state constitutional amendment was compromised by continuing constitutional reference to the dominance of the CCP. ${ }^{15}$ Peerenboom alternatively suggests that the 1999 amendment "may turn out to be more significant than the skeptics suggest" as the Party leaders are increasingly prepared to acknowledge that a law-based order is necessary to economic development and to the Party's own legitimacy. ${ }^{16}$

While Lubman seemed more intent upon making genuine rule-of-law making contingent on regime change, he stressed the importance of American engagement with Chinese legal reform: "Demonizing China will not contribute to enhancing institutions that can protect human rights, while engagement in legal reform projects could possibly have constructive effects that would be welcomed by many Chinese and by foreign observers." 17

Jonathan Hecht also made a plea for engagement before the Congressional Executive Commission on China on 11 April 2002, and he remarked on the paradox of domestic law as "the principal medium" through which the Chinese are experimenting with human rights development:

Whereas under Mao law was viewed solely as a "tool of the proletariat dictatorship," it is now being called upon to play multiple roles in economic and social life including defining rights and establishing institutions and procedures for their protection. In many respects Chinese law still falls far short of international human rights standards.... However, as paradoxical as it may seem, law is simultaneously the principal medium through which the Chinese are engaging in debate and experimentation about human rights and closely related issues of predictability, transparency, and accountability of state action. ${ }^{18}$

For many non-governmental organizations critical of China's human rights performance, however, the $F L G$ crackdown has illustrated the unremittingly recidivist character of Chinese "state instrumentalism."

14. Linda Chelan Li, "The rule of law in Guangdong," The China Quarterly, No. 161 (March 2000), pp. 119-220, our italics.

15. Stanley Lubman, "Prospects for the rule of law in China after accession to the WTO," http://www.law.berkeley.edu/institute, p. 3.

16. Peerenboom, China's Long March, p. 61.

17. Lubman, "Prospects for the rule of law in China after China's accession to the WTO," p. 3.

18. Jonathan Hecht, "Can legal reform foster respect for human rights in China?" Testimony before the Congressional Executive Commission on China, 11 April 2002, p. 2. 
Human Rights in China, for example, reported to the British House of Commons Foreign Affairs Committee:

The campaign against Falungong is part of a wider effort to restrict freedom of association by ensuring that all "legal" groups are strictly monitored to make sure their activities conform with the leadership's objectives and concerns and by ruthlessly suppressing any efforts to organize independently, whether around issues of religion, politics, human rights or protecting workers. ${ }^{19}$

In a separate report, Human Rights in China stated that the 1996 CL has already "departed substantially from both the letter and spirit of the law." ${ }^{20}$ Human Rights Watch similarly attacked a Chinese government contention that its actions against the FLG supported the "rule of law" and concluded: "The Chinese leadership's attempt to contain the Falun Gong is part of a broader government effort to try to control all organizations, religious, civil, social, or economic." 21

Indeed, the CCP's response to the FLG, as a "heretical cult," is rooted in its historical preference for an "instrumentalist" approach to law and social control. The "FLG problem" has complicated the contemporary market-related focus on human rights protection under the rule of law. It has not only raised difficult questions about freedoms of assembly, demonstration, religious belief and conscience. The regime's response to its "problem" has adversely affected internal debates concerning the importance of judicial independence and the substitution of judicial interpretation for legislative responsibility in the justice system.

For a long time, heretical cults were an ideologically construed matter of "counter-revolutionary crime." The latter was formally replaced by a new crime concerning state security in the 1997 CL revision, but this analysis still considers the degree to which the current legal treatment of the FLG reflects the Party's old zheng fa dynamic.

In the years leading up to the 1996-97 revisions, China's jurists vetted "human rights protection" vis-à-vis the state's reflexive resort to flexibility and analogy and gained a new measure of Party support for emphasis on the rule of law and human rights as these were seen as contributing to social stability in a time of rapid socio-economic change. In the context of the 1996-97 CPL/CL revisions, jurists argued for the exclusive reference in law to the twin principles of "no crime without a law" (nullum crimen, sine lege) and "no punishment without a law" (nulla poena, sine lege) in self-conscious rejection of analogy and flexibility. ${ }^{22}$ The current legal treatment of the "FLG problem" is at odds

19. Human Rights in China, "Human rights situation in China and the dialogue on human rights," 29 July 2000, http://iso.hrichina.org, p. 3.

20. Human Rights in China, "Empty promises: human rights protections and China's criminal procedure law in practice," http://iso.hrichina.org, p. 2.

21. "China uses 'rule of law' to justify Falun Gong crackdown," Human Rights Watch World Report 1999, http://www.hrw.org/press/1999/nov/chinal 109.htm. p. 1.

22. Ronald C. Keith and Zhiqiu Lin, "To revise or not to revise China's law on counterrevolution," China Information, Vol. 5, No. 4 (Spring 1991), pp. 24-26. On the differentiation of "counter-revolution" and "endangering state security," the balance of values and the redefined purposes of Chinese criminal law see "Balancing society and the individual in judicial justice," in Keith and Lin, Law and Justice in China's New Marketplace (London: Palgrave Press, 2001), pp. 178-231. 
with this rational trend of criminal law reform, and there is a conspicuous lack of concerted response within the legal circles to the "FLG problem" as an issue in human rights law.

Since 1999 the principle of "flexibility" has been re-invented, and the legal circles have not properly debated the law's treatment of the FLG as a "heretical cult." Moreover, sources within the judicial system have suggested that the $\mathrm{CCP}$ has usurped the provincial high courts and municipal middle-level courts in determining crime and punishment particularly in the two key areas, relating to the "FLG problem" and senior-level official corruption.

The CCP's response to the Tiananmen Square "turmoil" constitutes a rough benchmark for understanding the current treatment of "heresy" in law and politics. In the wake of the 1989 events, there were many cases of administrative action resulting in education through labour, but there were also many reported cases of trial proceedings concerning "counterrevolutionary crime." 23 Deng Xiaoping directed that the criminal law punish key organizers of illegal organizations, but that student demonstrators and petition signers not be tracked down. On 6 June 1989 he cautioned the Politbureau:

We also need to watch our methods as we take control of the situation. We should be extra careful about laws ... on assembly, association, marches, demonstrations, journalism, and publishing. Activities that break the law must be suppressed.... We've got to make it understood both inside and outside China that we're tightening control for the sake of stability, which means for the sake of reform and opening and modern construction. ${ }^{24}$

However, many of the recent cases relating to FLG members have not made it into court. The Ministry of Justice asserted its right to approve PRC lawyers seeking to represent FLG members and admonished them to interpret the law in such a way as to conform to the spirit of the government's decrees on the "FLG problem." ${ }^{25}$ Moreover, the Supreme People's Court instructed the lower courts to focus on social stability and the authority of the state. Judges were reminded of the importance of the

23. For discussion of the application of the law on counterrevolution to Tiananmen organizers see Timothy Gelatt, Criminal Justice with Chinese Characteristics (New York: Lawyers Committee for Human Rights, May 1993), pp. 77-81 and Keith and Lin, "To revise or not to revise China's law on counterrevolution," pp. 39-41. Gelatt reported (p. 80) that PRC legal scholars had told the Lawyers Committee that there was no likelihood of revision to the counter-revolutionary law in the foreseeable future. Keith and Lin suggested (p. 24) that the reaction to Tiananmen Square was only temporary and that the proposed revision would probably come back.

24. Andrew Nathan and Perry Link (comp. by Zhang Liang), The Tiananmen Papers (New York: Public Affairs, 2001), p. 424.

25. Based upon his discussion with James Seymour, Danny Schechter, Falungong's Challenge to China: Spiritual Practice or "Evil Cult" (New York: Akashic Books, 2001), p. 198. The case of Chen Zixu, which was later considered by the UN Committee on Torture, is but one example. Mrs Chen's daughter was unable to file a lawsuit to gain possession of her mother's body as no lawyer was willing to accept her case. For this item, "A deadly exercise: practicing Falun Gong was a right, Ms Chen said, to her last day," Wall Street Journal, 20 March 2000 and other related human interest stories see Ian Johnson's Pulitzer Prize reporting at http://www.pulitzer.org/year/2001/international-reporting/works/falungongl.html. 
rules of evidence, but they were told to deny the FLG the use of the courtroom as a public platform. Moreover, the Supreme People's Court required that the lower courts not accept FLG practitioners' civil suits against Li Hongzhi ostensibly for fear that this would politicize the judicial process. $^{26}$

In many of the cases against FLG organizers, the government resorted to administrative discipline. The accused were given two to three years' hard labour in the Public Security Administration's labour education system. US State Department reporting claimed that as many as 5,000 were sentenced to up to three years of re-education. The same human rights reporting pointed to the growing number of deaths of FLG members while in the custody of public security. The FLG case was also featured in a more broadly conceived critique of the revised CPL which was faulted for no law of evidence and for failing to address "custody and repatriation," lengthy detention for "further investigation," re-education through labour, the lack of provisions concerning the right to remain silent, and double jeopardy. ${ }^{27}$

In the spring of 1989, the legal circles' case against the law on counter-revolution was aired at the NPC just prior to the demonstrations in the Square. These same arguments were immediately shelved in the face of "counter-revolutionary turmoil," but they later succeeded in the 1997 CL revision. Persistent jurist pressure and related national discussion yielded a newly constructed balance between the requirements of rights protection and public order.

This balance, however, was not maintained in the treatment of the $F L G$, and China's "FLG problem" has become a hot issue in international human rights diplomacy. On 18 November 1999, for example, the US House of Representatives chastised the Chinese government, calling for the freedom to practise FLG spiritual exercises. The Chinese were criticized for an inappropriate banning of "cults." The Americans, on the other hand, were criticized for their rude interference in China's attempts to restore public order.

The Chinese claimed that the FLG is an "evil cult" and not a "religion," and that Li Hongzhi, the criminal founder of the $F L G$, long ago treacherously "exposed his horse's hoof beneath his unicorn skin."28 Ironically, the CCP deployed "feudal" metaphor to attack "feudal superstitution." The FLG rejected the CCP's attack on "superstition" as unscientific, political labelling, ${ }^{29}$ and insisted that its "cultivation practice" is neither religious nor political in nature. As early as 3 September

26. Peerenboom provides a informative analysis of the 5 November 1999 SPC "Notice concerning the implementation of the 'Decision of the NPC Standing Committee on banning heretical organizations and preventing heretical activities'," China's Long March, pp. 99-101.

27. US human rights reporting has focused its criticisms on re-education through labour. US State Department, Country Reports on Human Rights Practices-2000, February 2001, at http://www.state.gov/g/ddrl/rls/hrrpt/2000/eap/index.cfm?docid-684, pp. 6, 10-11.

28. See "Spokesman criticizes US House resolution on Falungong," Zhongguo Xinwenshe, Beijing, 19 November 1999 in FBIS-CHI-1999-1119, p. 1.

29. Li Hongzhi, "Further comments on superstitition," 13 July 1999, in Schechter, Falun Gong's Challenge, p. 267. 
1996, Li Hongzhi had disavowed those corrupt practitioners who took advantage of dafa to get involved in politics.

Li did not want the $F L G$ to come under existing state law on religion, hence the following conclusion of Professor Julie Ching: "The Falun Gong was careful not to make itself into a religion. In China, it had no temple, no official headquarters, no formal rituals, and it exacted no fees from its followers. Its gatherings were always in public." ${ }^{30}$ Prior to 1999 , the FLG enjoyed a loose affiliation with the State Sports Administration. Paradoxically, its own interdiction against religion made it more attractive to CCP members who were otherwise careful not to get involved in religious groups. ${ }^{31}$ When, on 25 April 1999, FLG members mobilized in front of Zhongnanhai, they requested that the government recognize the FLG not as a patriotic religious organization but as an independent state-sanctioned organization, distinguished by its "cultivation system" or "spiritual belief system." 32

Although the CCP and FLG have agreed that the latter is not a religion, for several years in a row, the US Secretary of State has named China as a "country of particular concern" under the International Religious Freedom Act of 1998. The US State Department's 2001 report on international religious freedom focused on increasing domestic suppression of unregistered religious groups as well as of "spiritual movements." The report claimed that the crackdown on the $F L G$ 's spiritual movement was having "a spillover effect on unregistered churches, temples, and mosques." 33 Subsequently, the US Commission on International Religious Freedom made a series of recommendations in its 13 February 2002 report on China that included a call on the Chinese government to reform its "repressive legal framework" as it relates to religious and spiritual organizations. ${ }^{34}$

Since the mid-1980s, there have been several stages of debate concerning the nature, scope and content of the "rule of law," and the contemporary "FLG problem" is but one of these stages; however, it offers an opportunity to place the legal and political issues of religious freedom and assembly within the wider frame of human rights formation and protection in an advanced context of accelerated economic reform.

The "FLG problem" surfaced even as the state constitution was revised in March 1999 to incorporate new reference to a Chinese socialist style of rule of law. Moreover, the it stimulated a conservative tendency within the CCP leadership to give equal weight to the rule of law, $f a z h i$, and rule of virtue, dezhi. The CCP called for state-led morality as it connected the

30. Julie Ching, "The Falun Gong: religious and political implications," American Asian Review, 1 January 2001, p. 2.

31. Ibid. p. 4.

32. Ian Adams, Riley Adams and Rocco Galati, Power of the Wheel: The Falun Gong Revolution (Toronto: Stoddart Publishing, 2000), pp. 8, 29.

33. Bureau of Democracy, Human Rights and Labor, US Department of State, International Religious Freedom Report, China (Hong Kong and Macau), p. 1 at http://www.state.gov/g/drl/rls/irf/2001/5752.htm.

34. US Commission on International Religious Freedom, Recommendations for US Policy on China, 13 February 2002, p. 2 at http://www.uscirf.gov/reports/13Feb02/ChinaRecommendations.php3. 
FLG problem with the US strategy of "Westernization" and "disintegration."

In the aftermath of Tiananmen Square, Jiang Zemin was said to have grasped and endorsed the rule of law as distinct from rule by man. ${ }^{35}$ In March 1999, Jiang supported the revision to the state constitution regarding "running the country according to the rule of law." 36 However, in a speech on 10 January 2001, he resurrected the mid-1980s combined rule of law and rule of man (fazhi he renzhi):

... we should persistently strengthen the construction of a socialist legal system and govern the country according to law. It is equally important to govern the country with high morals ... Ruling the country according to law and governing the country with high morals complement and promote each other. Neither ... should be overemphasized to the neglect of the other. ${ }^{37}$

Jiang extolled the rule of virtue as he abominated the "strong impact" of the "absurd fallacies" of the FLG as well as that of "Western capitalist theories and corruptive ideologies." "38 Apparently, the CCP leadership considers "normal" religious affiliation and belief as a positive aspect of the rule of virtue. While CCP members were disciplined for participation in the FLG, they could still join in "normal" religious activities. ${ }^{39}$

Jiang's personal role in the FLG crackdown has been the subject of Western media speculation. In April 1989, Shanghai, under Jiang, was the first to express its support for the suppression in Tiananmen Square. According to FLG sources, in April 1999, the Party Secretary General apparently disagreed with Premier Zhu Rongji who wanted a more measured approach to the " $F L G$ problem." ${ }^{40}$ Peerenboom's interpretation

35. In a 26 September 1989 interview with R.C. Keith, Sun Guohua, a leading jurist, indicated that in his recent discussions with Jiang Zemin the latter endorsed "rule of law" as an ethos which implies the limitation of the Party State in the supremacy of law. As cited in Keith, China's Struggle for the Rule of Law, p. 16.

36. See Keith and Lin, Law and Justice in China's New Marketplace, p. 35.

37. Party Literature and Research Department, Central Committee, Communist Party of China (ed.), Jiang Zemin, on "The Three Represents" (Beijing: Foreign Languages Press, 2001), p. 162. The combination idea was in the mid-1980s represented as especially appropriate to Chinese culture. See Keith, China's Struggle for the Rule of Law, pp. 15, 222-23.

38. Jiang Zemin, On “The Three Represents,” p. 163.

39. During a Politburo meeting in December 2001, Jiang Zeming stressed the social contributions of religion and praised the role of the "broad believing masses." "Giving China's Communist Party some of that old-time religion," Globe and Mail, 19 February 2002, p. A13.

40. A FLG press conference of 25 April 2001 claimed that Zhu had met practitioners just outside the State Council and that as a result of his more moderate approach to the problem, Jiang forced him to do a "self-criticism." Jiang's strong-arm tactics against the FLG were related back to his resolute role as Shanghai's mayor in suppressing the spread of demonstrations in that city in 1989. See Schechter, Falun Gong's Challenge to China, pp. 13,29 . If so this would have come just after Jiang and Zhu had made strong common cause in favour of Zhu's April 1999 trip to Washington to advance the WTO negotiations. The disagreement may have focused on the nature of $F L G$ organization rather than over whether the silent congregation around Zhongnanhai was detrimental to social stability as suggested in "Handling the Falungong case," trans. by Zong Haiwren from the Chinese, Zhu Rongji zai 1999 (Zhu Rongji in 1999), in Chinese Law and Government, Vol. 35, No. 1 (January/February 2002), pp. 53-72. 
in fact suggests that Zhu's approach would have involved more open and fair trials:

Although it might strike some as naîve to expect that the ruling regime would have responded to 10,000 people surrounding Zhongnanhai in a measured way, Zhu Rongji and other leaders apparently did favor a more measured response. Unfortunately, the regime appears to have missed a chance to gain legitimacy and strengthen the role of law, and to begin to articulate a long-term policy on just what kind of social activity will be tolerated. ${ }^{41}$

The difference between "normal religious activity" and the practice of feudal superstition critically affects freedom of assembly and religious belief in China. There is an estimated total of 200 million religious adherents in China ${ }^{42}$ and the issues of assembly and religious freedom form part of a larger puzzle concerning the potential for rule-of-law making and cognate human rights formation and their procedural protection in the PRC.

The protection of individual rights, particularly in terms of the practice of religious belief and the rights of freedom of expression and demonstration, is becoming more complicated as it involves the weighing of differently conceived rights across constitutional and national legal and political cultural settings. International human rights instruments have considered placing lawful limits on states so that they do not unduly restrict the freedom to manifest religion, but they have yet to define the concepts of "sect" and "new religious movement" as these entities relate to the changing domestic and international priorities of public safety. ${ }^{43}$

Certainly the CCP saw in the FLG's misappropriation of a popular indigenous Chinese culture a messy legal and political matter of public order that threatened to create a contagious spread of socially harmful "superstition." Favourable internal Party member perception of the innocuous semi-Buddhist nature of the FLG made it all the more threatening to the survival of the regime that everyone knew was in a state of axiological confusion. Somehow the Party, as the custodian of Chinese nationalism and culture, had to find a way to target the FLG without placing itself in opposition to a popular Chinese recreational activity and while preserving established policy on "religious freedom" and the policies of the open door and economic reform.

The FLG was accused of deliberately sowing socially harmful confusion. Ye Xiaowen, the director of the State Bureau of Religious Affairs, elaborated:

How is the common practitioner supposed to know that his or her "Master" has so many motives, and how is the practitioner supposed to know that his or her

41. Peerenboom, China's Long March, p. 98.

42. The US State Department cites the official government white paper that claims there are 200 million religious adherents, 3,000 religious organizations, 300,000 clergy and 74 religious colleges. Country Reports on Human Rights Practices 2000, p. 24.

43. Abdelfattah Amor, January 1998 report on the "Elimination of all forms of intolerance of discrimination based on religion or belief," as cited and discussed by Peerenboom, China's Long March, p. 95. 
organization has so many characteristics like an evil cult? They are also unclear that the "Falun" Buddha Law organization has already created great harm towards society and the people. The practitioners have all had the wool pulled over their eyes, and have been deceived. Even more pitiful is that their psyche is under the control of others.... ${ }^{44}$

The issue of "social harm" has been debated more generally in the course of criminal law reform. While some reformers accepted it as an appropriately rational component by which the law would make a determination as to whether any act constituted a "crime," critics protested that it amounted to an unnecessary Chinese exceptionalism.

Chinese allegations against the FLG also focused on the political difference between "normal religious activities" and the organization and use of secret cults to cause social harm. Such allegations included extensive references to the "criminal" use of superstitution against the cult's own members; for example, Xia Yong of the CASS Institute of Law contended:

... the "Falungong" organization and its activities have harmed the physical and psychological well-being, lives and the security of property of "Falungong" practitioners. Firstly, they have used such heresies as "the end of the world" and "global explosion" to confuse practitioners, thus causing some practitioners to lose the ability to think, judge, and discriminate things normally; they become distraught; behave in an eccentric and unreasonable manner, and even cripple themselves, commit suicide, or cruelly injure or kill other people. Secondly, they have asked believers not to visit the doctors when they are sick ... ${ }^{45}$

This particular argument invites an open-ended extension of the purpose and object of criminal behaviour. There is no clear distinction in law here between the harm done and the "scientific" criminal nature of "anti-social" activity. How, for example, can the law's rationality cope with the following amateur political analysis by Ye Xiaowen?

Anti-social tendencies have two extreme modes. One mode is from a passive shielding against the world to hate of the world and suicidal tendencies. The other mode is a repugnance with society moving toward an insane anti-social bent. "Falun" Buddha Law is also irresistibly moving toward an anti-social perspective, continuously inciting the masses; at one moment they are surrounding this, then they are surrounding that, believing that when the situation is ripe they can begin surrounding Zhongnanhai. Actually, they are trying to display power ... The core elements of the "Falun" Buddha Law organization, in propagating the "canon" of Li Hongzhi, have openly stated that "shedding blood is alright." 46

44. “Three Person Forum ...," Renmin ribao (People's Daily), Overseas edition, 19 August 1999, in FBIS-CHI-1999-0901, p. 4.

45. "CASS Official Xia Yong on Falungong, rule of law," Xinwenshe, Beijing, 3 August 1999, in FBIS-CHI-1999-0824, p. 1.

46. Central Television panel on the programme, "Focus," Fang Hongjin, programme host, Zhuo Xinping, Director of Research at the CASS Institute for World Religious Studies; Ye Xiaowen, Director, State Bureau of Religious Affairs, Renmin ribao (Overseas), 19 August 1999 in FBIS-CHI-1999-0901, p. 3. 


\section{The Law as Applied to the FLG}

As the result of $1997 \mathrm{CL}$ reform, the Party could no longer directly deploy law relating to "counter-revolutionary purpose" in its struggle with "feudal heresy." However, it still had several legal weapons in its arsenal. The FLG was accused of breaking a range of specific laws on publication, associational registration, demonstration and the illegal misappropriation of confidential state materials, and various sections of the Regulations on Governing Public Order and Security, related CL provisions with regard to disturbing "social administration order" and specific crimes dealing with illicit sexual relations and cult practices resulting in personal injury or death. ${ }^{47}$

There was a delay between the 25 April Zhongnanhai "demonstration" and the first legal decision regarding the banning of the FLG. On 22 July 1999, the Ministry of Civil Affairs finally declared that the FLG was an illegal organization that had failed to register under Article 7 of the November 1989 Regulations Governing the Registration and Administration of Public Organization. The FLG had also violated Article 19(3) of these same regulations, which forbade the creation of regional subsidiaries. Moreover, in conducting its activities without the benefit of registration, it had violated the companion Article 24(6) of the Regulations on Administrative Penalties for Public Security. ${ }^{48}$

Together with the regulations on assembly and demonstration which had been approved by the NPCSC on 31 October 1989, these regulations on registration had originally been cast in the aftermath of Tiananmen Square as a major revision to the September 1950 Interim Provisions on the Registration of Public Organization and had been drafted with reference to foreign legal experience. They had already been under consideration for ten years, but in 1989 there was some concern lest either the public or the lawmakers might be biased after Tiananmen Square and would rush to pass flawed legislation. ${ }^{49}$ The NPC lawmakers nevertheless forged ahead to pass the regulations in light of the law's "prolonged state of stagnation and lax administration" and so as to assert Deng's agenda for legal reform in the face of the great changes in society and the economy.

These permanent regulations were hailed as significant in a new period of reform during which the proliferation of all kinds of public organization was expected within the various spheres of cultural, scientific, economic and educational activity. They were designed to operationalize the 1982 State Constitution's provision on freedom of association, and they were characterized as part of Deng's reform entwining democratization and legalization in that they represented a dialectical unity of the

47. Much of the regulation was brought together in the Ministry of Public Security publication, Chajin qudi xiejiao zuzhi falü fagui (Laws and Regulations Prohibiting and Banning Heretical Cult Organization) (Beijing: Qunzhong chubanshe, 1999), passim.

48. "Falungong ban supported by law," BR, Vol. 42, No. 37 (13 September 1999), p. 9.

49. "New law on mass rallies took 10 years of effort," China Daily, 26 December 1989 , p. 4. 
citizen's right of association and the legal administration of public organization. ${ }^{50}$

The Deputy Minister of Civil Affairs, Li Baoku, defended the July 1999 ban indicating that indeed the Falun Dafa Research Society had not registered with the various levels of civil affairs organization and that Article 26 of the 1982 State Constitution regarding the freedom of religious practice did not apply to the $F L G$ as it was not a religion per se. The Deputy Minister quickly offered reassurances that the ban would not infringe upon the lawful practice of qigong. ${ }^{51}$

The PRC Law Governing Assemblies, Parades and Demonstrations had also involved years of study of international legal comparisons, but it had been passed in the immediate context of post-Tiananmen Square events. Like the law on registration it was introduced with reference to the need to balance the protection of citizens' rights with the state's need for public order. Nothing therein gave the Party an especially useful legal handle on the problem of "evil cult" activities.

This law dealt with the very slippery distinction between "legitimate" and "illegitimate" protest in light of the prevailing Dengist focus on democracy and the legal system as "twin sisters." ${ }^{2}$ However, the new law was interesting in its exclusion of non-residents from participating in locally approved demonstrations. As has been noted, one of the political issues surrounding the $F L G$ case concerned the unlawful extent of its organizational discipline across the various cities and regions of China. ${ }^{53}$

In facing the " $F L G$ problem," the authorities were dealing with an apparently unfamiliar and rapidly spreading passive aggressive behaviour. Collective meditation did not quite fit the mould of law circles' post-Tiananmen Square discussion of what constitutes legally defined protest. Moreover, in Article 2 cultural and sports activities are expressly excluded from the parameters of this particular law:

Demonstrations in this law refer to activities held in public areas or roads and carried out in the forms of assemblies, parades, or sit-ins to voice demands, lodge protests, or express support and other common wishes. This law does not apply to cultural, recreational, or sports activities; normal religious activities; nor traditional, nongovernmental activities among the people. ${ }^{54}$

50. "Commentary views public organization regulations," Renmin ribao, 9 November 1999 in FBIS-CHI- 89-230, 1 December 1989, p. 14.

51. Minzhengbu youguan fuzeren zhichu qudi Falun dafa yanjiushi yi fa zouchu de jueding (Ministry of Civil Affairs Official Spokesperson Points Out that the Decision to Ban the Falun Dafa Research Society was Based in Law), Renmin ribao, 24 July 1999.

52. Xiao Du, "Faithfully adhere to the principles of the constitution: sidelights on how the NPCSC examined and discussed the law governing assemblies, parades and demonstrations," Renmin ribao, 1 November 1989, p. 2 in FBIS-CHI-89-214, 8 November 1989, p. 25.

53. In her analysis, Julie Ching argues the importance of the state constitutional guarantee of freedom of assembly, but she indicates: "The government appears in the right when it describes the tight organization of the group which Li Hongzhi characterizes as spontaneous." Ching, "The Falun Gong: religious and political implications," p. 4.

54. Text of "The PRC law governing assemblies, parades and demonstrations," in FBIS-CHI-89-210, 1 November 1989, p. 16. 
Article 2 was reaffirmed in the June 1992 Article 4 of the Regulations for the Implementation of the Law of Assembly, Procession and Demonstration of the People's Republic of China. ${ }^{55}$ Presumably, any malicious practice of qigong could not be easily dealt with under the law dealing with public protest and demonstration. During the Zhongnanhai "protest" or practice of non-verbal meditation, $F L G$ organizers reportedly told their followers not to sit but to stand so that they would not be seen as having participated in an illegal sit-in. ${ }^{56}$

In the summer of 1999 the Ministry of Civil Affairs relied more on the law of registration, as distinct from that of assembly, and it issued on 22 July a public notice banning specific $F L G$ activities in accordance with CL provisions and the Regulations Governing Public Order and Security. These forbade, for example, the display of $F L G$ scrolls and symbols, the distribution of FLG books and videos, and demonstrations. In July 1999, the Information and Publications Office issued five notices requiring the confiscation of $F L G$ publications that allegedly spread superstition. ${ }^{57}$

On 29 July the Ministry of Public Security issued a warrant for the arrest of Li Hongzhi for spreading superstition and heresy resulting in death, and for illegal assembly for the purpose of disturbing public order. The CCP invoked the issue of organizing heresy as a criminal matter under the law. This opened up the possibility of pursuing a new generation of counter-revolutionaries or heretics even in the absence of an explicitly stipulated criminal law on counter-revolution.

Prior to April 1999 there was very little relevant experience with the application of related provisions of the $1997 \mathrm{CL}$. Li stood accused of violating the key Article 300 of the 1997 revised Criminal Law, which, unlike Articles 99 and 165 of the 1979 CL, did pay specific attention to "evil cults." Article 300 dropped the 1979 Article 99 reference to "counter-revolutionary purpose," but it criminalized "organization," purposefully designed to undermine the implementation of law and administrative regulation. At the time of revision, several legal experts had alternatively stressed that organization in itself ought not to be construed as criminal in nature. The commission of a crime required that such organization had undermined specific state law and regulation. ${ }^{58}$

Also, the law offered a typical distinction in sentencing depending on the degree of severity of such crime. Zhou Daoluan and his Supreme People's Court colleagues, Shan Changzong and Zhang Sihan, suggested that serious circumstances might be interpreted in terms of six

55. Charles D. Paglee, "China law web, regulations for the implementation of the law of assembly, procession and demonstration," http://www.quis.net/chinalaw/prclaw113.html.

56. This is as reported by a Renmin ribao staff reporter, see "Spontaneous' or premeditated - second commentary on exposing the essence and harm of "Falun Gong,," Renmin ribao, 6 August 1999 in FBIS-CHI-1999-0906, p. 2.

57. Chinese texts of the central government and Party documentation on the case against the FLG are provided in a single issue of Xinhua yuebao (New China monthly), No. 8 (1999).

58. Zhang Qiang (ed), Xiuding xingfa tiaowen shiyong jieshuo (Explanations of the Application of the Revised Criminal Law Articles) (Beijing: Zhongguo jiancha chubanshe, 1997), p. 388. 
categories relating to the recruitment of followers across the country and the involvement of large numbers of people; collusion with superstitious sects, secret societies and cults in other countries; leadership and organization; the instigation of the masses to resist state law and the related injury of state officials; deception resulting in suicide; and causing social disorder and the stoppage of production. ${ }^{59}$ The first three categories focused on the mere existence of organization, whereas the last three tied the extant organization to specific criminal actions that disrupt the administration of social order.

Recruitment per se is not widely seen as inherently "criminal," nor for that matter is organizational size. The Party, however, accused the FLG of widespread disinformation through the manipulation of classified state documents. Renmin ribao, for example, reported on how the Ministry of Public Security put together a relevant case in October 1999:

[The $F L G$ ] intended to create a situation in which the practitioners were antagonistic to the party and government, and the law could not lay blame on the masses. In addition, they tampered with and distorted some of the meanings in the internal documents, and disseminated extensively through the internet, and incited the masses who were unaware of the truth to be discontent[ed] with the party and government. $^{60}$

Truth in publication has always been politically sensitive. The $1979 \mathrm{CL}$ incorporated a revised stipulation in Article 102 concerning the distribution of scrolls and pamphlets for counter-revolutionary purposes and Article 170 dealt with pornography. Article 102 was simply deleted. Article 170, however, was re-stated in Article 363 of the 1997 CL. The November 1999 joint interpretation in its criminalization of publication and distribution of cult materials and its prescription of "severity" in relation to the widespread publication and distribution of such materials as constituting "severe circumstances" would seem to stretch the original legislative intent of Article 300, and in fact, parallels that of Article 102 in the $1979 \mathrm{CL}$ - an article which had been eliminated together with all the criminal law references to counter-revolutionary purpose. The latter had been rejected as anti-scientific and politics had been cited for obscuring the predictability and clarity of law.

In fact, the criminality of organization relies on the extent to which a cult or secret society is proven to propagate heresy and superstition at the expense of public order and social administration. Such an open-ended and possibly tautological determination of "heresy" could well place any "religious" activity in legal jeopardy. Li Chun and Wang Shangxin, criminal law experts at the powerful Legal Work Committee of the NPC's Standing Committee, however, offered assurances that an "evil cult," unlike a legitimate religious organization, does not have a perma-

59. Zhou Daoluan, Shan Changzong, Zhang Sihan, et al., Xingfa de xiugai yu shiyong (The Revision and Application of the Criminal Law) (Beijing: Renmin fayuan chubanshe, 1997), p. 616.

60. Wang Lieming, "Falung said to disclose state secrets," Xinhuashe, Beijing, 25 October 1999, in FBIS- CHI-1999-1027, p. 2. 
nent place for worship; and it recruits followers through so-called "antisocial propaganda." ${ }^{\prime 1}$

Indeed, Article 2 of the 31 January 1994 Regulations Governing Venues for Religious Purposes had clarified that venues for religious activities would include monasteries, temples, mosques, churches and other fixed places and it required formal registration to establish such venues. ${ }^{62}$ However, the law was nevertheless burdened with determining "heresy" as it relates to membership, as well as to the use of organization.

\section{Judicial versus Legislative Interpretation}

Although there existed some law for dealing with the " $F L G$ problem," in itself it was apparently not enough. It had to be reinforced in either NPC decision or judicial interpretation. On 30 October 1999, the NPC Standing Committee (NPCSC) passed an unusual decision to eliminate $F L G$ activities. The decision announced policies to eliminate evil cult organization, to combine education and punishment in dealing with the deceived masses, to launch an educational movement to reveal the true essence of the $F L G$ challenge to society and civilization, and to mobilize against the FLG through the "comprehensive management of public order." ${ }^{33}$

The latter anticipates a co-ordinated state-society approach to public order, encompassing the judicial determination of crime and sentencing as well as various types of political initiative in the organization of related propaganda and education throughout society and all its institutions. Even at the level of the State Council, for example, government officials were exhorted to accept "three stresses" of theoretical study, political consciousness and healthy trends so as to arrest the spread of the "evil cult" into state agencies. ${ }^{64}$

As for the law's specific response, the 1997 CL Article 300 contained new reference to "evil cults" but it still did not clarify the degrees of severity of related crime. This understanding was provided in the specific joint formal interpretation of the Supreme People's Court (SPC) and the Supreme People's Procuratorate (SPP) on 1 November 1999. Related interpretation defined "evil cult" with reference to specified patterns of behaviour. Its effect was to expand the field of punishable behaviour under Article 300 and to increase the range of severe criminal rather than

61. Li Chun, Wang Shangxin et al., Zhongguo xingfa xiuding de beijing yu shiyong (The Background of Chinese Criminal Law Revision and its Application) (Beijing: Falü chubanshe, 1998), p. 395.

62. Charles D. Paglee, "China law web, regulations governing venues for religious activities," http://www.lqis.net/chinalaw/prelaw110.html.

63. "Guanyu qudi xiejiao zhuzhi, fangfan he chengzhi xiejiao huodong de jueding" ("NPCSC decision on eliminating cult organization, preventing and punishing cult activity"), Renmin ribao, 1 November 1999.

64. "Zhu Rongji discusses 'three stresses' campaign," Xinhuashe, Beijing, 19 August 1999, FBIS-CHI-1999-0819, p. 1. 
administrative law punishment with reference to other cognate articles in the criminal law. ${ }^{65}$

Such interpretation highlighted the respective interpretative powers of the legislature and judiciary. It has often been the practice to develop the detailed regulations for the application of national law subsequent to the latter's passage; however, in such a sensitive political case, one has to wonder whether the SPC and SPP were under stiff political pressure to make a convenient, but ex post facto determination of criminal law behaviour specifically with the FLG in mind. Such interpretation conveniently saved the NPCSC from having to go the notorious route of "legislative interpretation" at the expense of the principle of non-retroactivity. The new constitutional emphasis on "running the country according to law and building a socialist rule-of-law" had partly originated with a critique of early 1980s NPCSC decisions, which were challenged as retroactive and in contradiction with "no crime, and no punishment without law."

Had the NPCSC exercised its own power of legislative interpretation, legally it would not apply to the $F L G$ case, as its leaders were already under arrest. For decades, there has been a lack of consensus in legal circles as to what specific authorities have the right to interpret the criminal law, and, for Western human rights critics, this raises a serious problem of the law's impartial independence from state institutions. The Chinese legal system is peculiar to the Western observer in its extension of the powers of judicial interpretation to a wide variety of central agencies.

Actually, NPCSC interpretation, although it has been the source of considerable controversy, has been rare. Between 1981 and 1990, over two-thirds of lawful interpretations originated with the joint pronouncements of the SPC and SPP whereas the rest involved the State Council, and the Ministries of Justice, Public Security, Health and Finance. While the NPCSC was seen to have violated the principles of no crime and no punishment without law in the early 1980s, it had at the same time attempted to regularize the process of judicial interpretation. And in the FLG case, SPC-SPP joint interpretation offered a way round the NPC retroactivity, but this came at a new cost to the clear separation of the functions of the judiciary with the legislature.

The unlimited power of the NPC and its Standing Committee to interpret legislation was entrenched in the 1982 State Constitution, but this sharply contrasted with the lack of a clear definition of the sources of judicial interpretation. "Rule-of-law" making has been complicated, if not compromised within the peculiar bureaucratic politics of the CCP's mass line principles of state organization.

The NPCSC's 10 June 1981 Decision Strengthening the Work of Legal Interpretation favoured interpretation by both the SPC and SPP. At the time there were objections to the inclusion of the SPP as a law enforce-

65. "Guanyu banli zhuzhi he liyong xiejiao fanzui anjian juti yingyong falü ruogan wenti de jieshi" ("Interpretation of several questions in law concerning criminal cases or organizing and using evil cult organization"), Renmin ribao, 1 November 1999, p. 2. 
ment agency rather than a judicial agency responsible for the legal determination of crime and the imposition of punishment. ${ }^{66}$ There was also sharp criticism of the scope of judicial interpretation and the related potential for the judiciary's misappropriation of legislative responsibility. In 1998, Chen Sixi, a legal expert at the NPC's Legal Work Committee, called for a clear distinction between the legislative and judicial interpretation of law. The former embodied the abstract creation of law while the latter featured an understanding or interpretation of concrete points of law with reference to specific cases. By limiting judicial interpretation to specific cases, should any errors occur, the negative consequences of these would be limited to the individual cases and would not necessarily undermine the inner logic of law as it relates to the "rule of law" versus non-retroactivity. The latter, however, ran the risk of judicial interpretation moving beyond the specifics of a particular case to expand the original content of legislation. ${ }^{67}$

Chen's view has been voiced a number of times but it is not yet widely accepted, and there is still an unfocused diversity of expert opinion on the issue of interpretation. Even in the traditional terms of mass organizational imperative, expansive judicial interpretation might be construed as seriously undermining the separation and combination of functions between different governmental agencies. ${ }^{68}$ But the same tradition gave priority to "flexibility" and alternatively reinforced argument to the effect that the powers of interpretation ought to be widely shared so that, at a wider variety of institutional points, the law can more directly respond to changing social realities. ${ }^{69}$ This viewpoint conflicted with the reform interest in no crime and no punishment without law, and the newly conceptualized balance between emphases on social control and the procedural protection of human rights.

The interpretation of the first section of Article 300 is important in light of such controversy. Article 300 identified six categories of criminal behaviour, concerning political action and purpose that allegedly undermines the social administration of public order: the gathering of the masses to attack and to disrupt the activities of state organs, enterprises and social organizations; illegal assembly, demonstration, occupation or the disturbing of public places and normal religious activities; the revival of cult organization previously dismantled by the state order, or the creation of new cult organization; instigating or deceiving others to disobey the law; the printing, publication and copying of illicit cult materials; and finally a standard catch-all with a long history of nefarious

66. See You Wei and Zhao Jianfeng, "Lun woguo xingfa sifa jieshiquan de guishu wenti" ("On the issues concerning power of judicial interpretation of our criminal law"), Faxue yanjiu (Studies in Law), No. 1 (1993), p. 58.

67. See Chen Sixi, "Lun lifa jieshi wentide shiyu fei jiquita" ("On questions concerning legislative interpretation and other issues"), Zhongguo faxue (Chinese Legal Science), No. 3 (1998), p. 63.

68. See Keith, China's Struggle for the Rule of Law, p. 82.

69. See, for example, Yin Yijun and Chan Jinzhao, "Sifa jieshi lunxi" ("Discussion and analysis of judicial interpretation"), Zhengfa luntan (Law and Political Science Forum), No. 1 (1994), p. 35. 
association with the key principle of "flexibility," namely, "other conduct violating state law and regulation."

The state's political and legal response to the " $F L G$ problem" has revealed the competing political and institutional influences affecting contemporary rule-of-law making in China as well as the serious definitional problems associated with the law's treatment of religious freedom and assembly. Certainly, the issue of law and heresy and the issues surrounding the criminality of organization, as distinct from the criminal use of organization, have highlighted the potential abuse of the rule of law within the Party's updated mass line traditions. These trends conflict with the 1996-97 effort to enhance criminal justice based upon a "balance of values."

\section{Conclusion}

One could argue that in any place the struggle for the rule of law is not only open-textured but multifaceted, unremitting and never ending. ${ }^{70}$ China in transition, however, is a place of a hundred contradictions. Correspondingly, the struggle for the rule of law is uneven and episodic, if not spasmodic. While Western scholars have been generally mixed in their view of the 1996-97 CPL/CL revisions, most would accept that these revisions represented a progressive qualification of the pre-reform zhengfa dynamic which subordinated law to policy and elevated the principles of flexibility and analogy. "State instrumentalism" was formally challenged in the 1996-97 reforms, and it is this context that the contemporary legal response to the "FLG problem" is disappointing. The law is threatened with politicization as the CCP leadership has succumbed to its own worst instincts in its rush to crack down on the FLG.

Since 1985, the progressive conceptualization of the rule of law came about in domestic response to, first, the self-consciously articulated need for law and stable government in light of the tragic political extremes of the Cultural Revolution; secondly, the need for law as a predictable predicate facilitating the business of a modern economy; thirdly, the attempt to guarantee, in law, new "rights and interests" (quanyi) in a society undergoing profound value change; and finally the need to arrest deepening corruption, which is seriously engulfing the judicial process itself. In this volatile context, policy exigency can be used to rationalize "state instrumentalism," but it may also serve to qualify the arbitrary character of the party-state and to further the legitimate role of law in a fast changing society.

Clearly, the Jiang Zemin leadership was unable to meet the FLG's challenge to its own authority within the discrete application of narrowly stipulated criminal law. While fully considering the negative aspects of the legal response to the $F L G$, this article agrees with Lubman and Hecht on the need for engagement with the PRC. There is some hope that

70. Rather than using "open-textured," Randoph Peerenboom discusses "thick" and "thin" versions of the "rule of law" and analyses how different constitutional regimes including China can attempt to move towards the rule of law. Peerenboom, China's Long March, pp. 5-6. 
China's entry into the World Trade Organization will encourage trends towards state transparency and the international "liberal" norms of legal institutionalism. ${ }^{71}$ It is constructive to recognize any internal arguments which still support the rule of law in terms of "equality before the law" and "supremacy of law." At the same time, it is important to identify political trends that work against the progressive aspects of the 1996-97 reform.

The CCP response to the "FLG problem" points to the dangers of a resucitated state instrumentalism in the ever deepening context of China's social and economic transition. The rule of law has recently been saddled with the rule of virtue. Contention that the regime's legal treatment of the $F L G$ supports the struggle for the rule of law is hardly compelling. In the modern era of economic reform and information revolution, the Party is using law for the political purpose of leading a moral charge against heresy!

The Party co-opted the SPC to deal with "heresy" and this politicization has challenged reform argument for narrow judicial interpretation that focuses on the need for the comprehensive stipulation of new crime and on the specifics of criminal cases so as to avoid trenching on the legislature's role to make law. This co-optation represents a new modality of "flexibility" that challenges judicial independence. At the same time, Party policy has also muddied the issue of "criminality" as it has highlighted mere membership in organization as new crime. Furthermore, by tying the rule of law to "heresy," the CCP is reinforcing anachronistic mass-line arguments favouring "comprehensive management of public order" and the need for a variety of state institutions to interpret the law in an overt ideological way so as to consolidate "socialist spiritual civilization." Judicial independence is thus demeaned as the state acts as the custodial parent of preconceived mass morality rather than as the impersonal but fair arbiter of individual rights protection.

While the Chinese leaders have treated the $F L G$ as a heretical cult rather than as a religion, their approach may well expose religious and cultural organization to more threatening state scrutiny. The possible charge of "heresy" will always be out there lurking in changing Party politics. "Heresy" is in some sense a cross that reformers have been made to carry in their struggle to entrench the rule of law. Moreover "flexible" judicial interpretation threatens to subvert the proper role of the legislature as it is based upon "no crime, no punishment without law." The ballooning of the substantive content of Article 300 of the 1997 CL, through inappropriate resort to SPC-SPP interpretation, invokes the hoary principle, "policy is the soul of law." This trend is likely to elevate a reconstructed principle of "flexibility." It may subordinate the law within the wider political framework of the comprehensive management of public order, calling into question the supremacy of law and thwarting the efforts of jurists who for many years have struggled to articulate a new balance of values synthesizing social protection and public order with human rights protection. 